\title{
Contesting sub-state integration policies: migrant new speakers as stakeholders in language regimes
}

\author{
Anna Augustyniak ${ }^{1}$ (1) Gwennan Higham ${ }^{2}$ (1)
}

Received: 8 November 2017 / Accepted: 14 December 2018 / Published online: 27 February 2019

(c) The Author(s) 2019

\begin{abstract}
This paper aims to illuminate the role of sub-state languages in the integration process of migrants in two sub-state regions: Wales in the UK and the Basque Autonomous Community in Spain. We investigate how language and the idea of 'belongingess' based on language learning and knowledge are constructed in the integration policies in these two officially bilingual regions. We analyse policy documents on the topic of integration of migrants in the respective state and sub-state regions, as well as exploring how the role of language is in turn understood, accepted or contested by migrants. Using ethnographically oriented methods of enquiry such as observations of linguistic practices as well as semi-structured interviews with migrant learners of Welsh and Basque, this analysis seeks to contribute to the growing field of LPP as a multifaceted area of study, and in this case, position migrants as agents in policy-making processes. We find that despite distinctive and ambiguous roles ascribed to the respective official languages of each region, migrant new speakers ascribe certain values and roles to each language, which are not necessarily acknowledged or envisaged as such in integration policies. We propose that taking the voice of migrant new speakers learners into account would improve language and integration policymaking in these two sub-state regions and help to redefine the role of language resources in national 'belongingess' according to the needs of the stakeholders involved.
\end{abstract}

Keywords Migrant integration $\cdot$ Minority languages $\cdot$ Belonging $\cdot$ Language policy $\cdot$ New speakers

Gwennan Higham

g.e.higham@swansea.ac.uk

Anna Augustyniak

Anna.Augustyniak@ iscte-iul.pt

1 CIES-IUL Instituto Universitário de Lisboa Edifício Sedas Nunes, Av. das Forças Armadas, 1649-026 Lisbon, Portugal

2 Welsh Department, Swansea University, Singleton Campus, Swansea SA2 8PP, UK 


\section{Introduction}

Increased migration to Europe has put the question of integration and language at the heart of current political and public discourses. Learning the state language is often elected as a sign, if not even the sign, of national 'belongingness' (Burns and Roberts 2010: 412). This is clearly the case in politically established nation-states who use language testing as a tool for the regulation of migration processes and official citizenship (for instance: the Netherlands, the UK or Germany; for a review see for example Extra et al. 2009).

Much less attention has been placed, however, on the relationship between language and integration in sub-state contexts, such as the ones we analyse: Wales and the Basque Autonomous Community (BAC). Both sub-states are coming to terms with managing relatively new linguistic policies regarding their indigenous languages as well as policies regarding the accommodation of new ethnolinguistic diversities brought by transnational migration. In this paper, we will analyse the role that state and sub-state languages play in the integration policies applicable in the two regions. In our analysis, we will use discourse analysis methods for a discussion of selected integration policy documents of both Spain and the UK, as well as the respective sub-state regions. We will then include a discussion of ethnographically oriented data to help illuminate the relationship between the policy regulations with regard to language and integration and their subsequent reception by migrants. We will consider migrants as actors in the process of integration, the role of each language in this process, as well as how migrants' role as sub-state language learners can be understood in divergent ways by policy makers and by migrant learners themselves. We argue that such a discrepancy proves to have not only social implications, related to integrative aspects of identity and 'belongingness', but also economic ones, for migrant new speakers as stakeholders in both state and sub-state linguistic regimes. We suggest that our comparison, based on ethnographically oriented methods, will contribute to giving voice to migrant new speakers, positioning them not just as 'neutral bystanders' (Kymlicka 2011), but rather as active stakeholders in policy making. ${ }^{1}$

\section{Theoretical approach}

Language regimes of nation-states tend to reproduce the ideologically informed ideas on homogeneity and state monolingualism in relation to National Citizenship, resulting in highlighting the 'otherness' of migrants (Blackledge 2004: 72-73). However, sub-state language policy makers usually lack citizenship regulatory powers and need to appropriate the relationship between language and 'belongingness' in a different manner. This is often done by appealing to the integrative role of the

\footnotetext{
1 What we mean by voice is the 'political dimension' of this concept, involving having authority and representation, but also the projection of relations between one's identity, experience and point of view (Keane 2000: 271).
} 
sub-state language, rather than to its legal or economic powers. In practice, this does not always mean that they do not reproduce the abovementioned ideological beliefs included in state policies. However, we find that the existence of sub-state integration policies is an attempt at socialising migrants into practices of multinationalism and of 'negotiating nationalism' (Norman 2006). Sub-state languages are also used by policy makers to represent a distinct culture into which migrants integrate. ${ }^{2}$ Because of this, new inhabitants of sub-state regions receive mixed messages as to the conceptualization of citizenship, 'belongingness' and the role of each language in national identity construction and in the integration process (Kymlicka 2011: 297).

Kymlicka (2011: 282) proposes that for integration models to be more inclusive of immigrants 'we need a more multinational conception of citizenship, and a more multicultural conception of multinationalism.' Multinational citizenship would mean the kind of citizenship that recognizes and validates sub-state national identities within the state, while multicultural multinationalism would include the varying characteristics and cultural backgrounds of migrants. On the level of language policy this may mean valuing the various linguistic resources of migrants as well, shifting from a 'native speaker' mastery of a linguistic code to include partial and 'imperfect' use of resources (O'Rourke et al. 2015). By acknowledging their needs and linguistic competences, migrants should cease to be treated as objects of linguistic integration, but rather become valid stakeholders and 'voices' in their own integration and language learning trajectories.

Migrants new speakers become another important set of actors in the revival of minoritized sub-state languages. Sub-state integration policies, therefore, play an important part in providing migrants with access to sub-state language resources. Top-down language policy assumptions can be verified and their implications can be discovered through ethnographic methods. McCarty and Liu (2011: 54) propose that ethnographic methods of language policy enquiry aim to discover not just the premises behind the official declarations, but also 'implicit policy processes', i.e. 'the ways in which people accommodate, resist and construct policy in their daily lives'. As well as the need for greater recognition of varying forms of state bilingualism, the new speaker concept sheds light on the diverse possibilities and functions that both sub-state and state language resources can fulfil in a variety of social and economic spaces. Rather than focusing on the debate between majority versus minority speaker or native versus non-native, new speakerness moves away from ethnolinguistic divides and opens up possibilities of including non-traditional speaker profiles and practices (O'Rourke et al. 2015). New speakerness also shifts from notions of language categorisations to support notions concerning the fluidity of language practices and repertoires. Migrant new speakers therefore allude to migrants who have settled in a region or sub-state and who start to learn and use the sub-state language in an active way (in addition to other languages including the state language).

\footnotetext{
${ }^{2}$ Quebec and Catalonia are examples of sub-states in which migrants are encouraged to use French or Catalan as the 'common' language, and where integration policies draw clear links between the sub-state language and issues of cohesion (Woolard 2016).
} 
In this paper, both contexts: BAC and Wales, are informed by separate doctoral research projects for which data was gathered through ethnographically oriented methods. Both projects discussed divergent research questions and aims. However, for the purpose of this paper, both research projects will be compared and contrasted in the attempt to answer the following questions:

1. How is the role of language defined in sub-state integration policies in Wales and the BAC?

2. How do migrants contest or comply with these policies?

We will thus deal firstly with the question of how state and sub-state language and integration policies in both contexts are represented and also how these two categories are appropriated, constructed and resisted by migrant learners of Welsh and Basque on the ground. To answer these questions, we will define 'policy' in ethnographic terms, as a nonlinear and polycentric process (Blommaert 2014). Linking to the discussion concerning the contribution of ethnography to re-envisioning language policy and planning (McCarty 2011), ethnography could likewise be significant for re-conceptualising integration policies of sub-state nations. This perspective on language policy, we believe, will show that migrants, in certain conditions, could be considered as active agents—stakeholders-in policy formation.

\section{Methodology}

Both research projects used ethnographically oriented methods of data collection and analysis to somewhat different purposes and research aims. Nevertheless, these methodological similarities allowed for the data in each project to be compared for the purpose of this enquiry. Additionally, in both cases, a discourse-analytical study of policy documents was carried out focusing on official state and sub-state governmental policies in relation to migrant integration and language learning. While the list of documents under analysis is not exhaustive, in the case of the BAC project, the documents included:

- Plan of Action for the Promotion of Basque 2012 (PAPE).

- The Spanish Strategic Plan on Integration and Citizenship 2007-2010 (PECI I) and 2011-2014 (PECI II).

- 1st and 3rd Basque Plan of Immigration, Citizenship and Intercultural Cohabitation 2003-2005 (I PVICCI) and 2011-2013 (III PVICCI).

- Second Basque Plan of Immigration 2007-2009 (II PVI).

They were also selected on the basis of their reference to contemporary migration, i.e. the turn in which Spain, including the BAC, became a state with a major influx of migrants (Carrera 2009). In the case of Wales the documents analysed were:

- Getting on Together: A Community Cohesion Strategy for Wales [WG 2009]. 
- Cymraeg 2050: A Million Welsh Speakers [WG 2017].

- Understanding Wales [WG 2010].

- Refugee Inclusion Strategy [WG 2008].

- English for Speakers of Other Languages (ESOL) Policy [WG 2014].

- Secure Borders, Save Haven: Integration with Diversity in Modern Britain [UK Gov 2002a, b].

- Integrated Communities Strategy Green Paper [UK Gov 2018].

The documents were then analysed thematically according to how the official languages in each region were depicted and how their role in state and sub-state 'belongingness' was represented in each document. Initially, sections related to Spanish, English, Basque, Welsh and both official languages in each region were highlighted. Each section was then categorised in relation to how it represented the role of each language in integration and 'belongingness'. These categories included either integrative or economic aspects of each linguistic set of resources. From this initial analysis it was concluded that the policy documents appeared to place different values on each official language in each area. We then compared and contrasted the extracts from Welsh and Basque documents and identified themes which appeared to be relevant to the research questions and which helped illuminate the similarities and differences between the two contexts, discussed in the analysis section, i.e. pluralist or civic integration, double, sub-state or single, state integration, local, cultural and economic integration. The document analysis allowed for a contextualisation of extracts from interviews conducted in each fieldwork. The document analysis enabled us to embed the extracts we use in social context.

The fieldwork project in Wales involved two geographical sites: Cardiff, the capital city (11\% Welsh speaking) and the county of Gwynedd North Wales (70\% Welsh speaking). Semi-structured interviews were carried out with government officials, English (ESOL) and Welsh for Adults language teachers as well as 40 interviews with immigrant students of Welsh and English in both sites. The participants in the Welsh case were all first generation migrants who had neither Welsh nor English as a first language, yet represented a diversified sample of characteristics in terms of first languages spoken, country of origin, as well as language studied (English/ Welsh) etc. Immigrant participants in this study are therefore noted as either Welsh for Adults students, ${ }^{3}$ ESOL students or Welsh Citizenship class students. Tables 1 and 2 below portray some of the noted characteristics.

Table 1 Participants in Wales by student category and location

\begin{tabular}{lcl}
\hline Student & Cardiff & Gwynedd \\
\hline ESOL student & 10 & 8 \\
Welsh for adults student & 6 & 9 \\
ESOL Welsh citizenship class & 15 & \\
\hline
\end{tabular}

\footnotetext{
${ }^{3}$ Welsh for Adults, the Welsh language provision for adults in Wales, is now referred to as Learn Welsh, run by the National Centre for Learning Welsh.
} 
Table 2 Participants in Wales by country of origin and first languages spoken

Country of origin and languages spoken

$\begin{array}{lll}\text { Europe } & \begin{array}{c}\text { Poland, Spain, Italy, Romania, Germany, } \\ \text { Greece, Netherlands }\end{array} & \begin{array}{c}\text { Polish, Spanish, Catalan, Romania, } \\ \text { German, Dutch, }\end{array} \\ \text { Africa } & \text { Algeria, Nigeria, Somalia } & \text { French, Arabic, Berber, Somali } \\ \text { Middle East } & \text { Oman, Iran, Kurdistan, Turkey } & \text { Arabic, Persian, Kurdish, Turkish } \\ \text { East } & \text { India, Malaysia, Thailand, Japan } & \text { Hindi, Tamil, Malai, Thai, Japanese }\end{array}$

Table 3 Participants in the BAC by language course and province

\begin{tabular}{lccc}
\hline Course & Alava & Guipuscoa & Biscay \\
\hline $\begin{array}{l}\text { AISA } \\
\begin{array}{l}\text { Euskaltegi and } \\
\text { other }\end{array}\end{array}$ & 22 & 6 & 9 \\
\hline
\end{tabular}

Interview topics focused around personal details and their migration stories as well as questions concerning their welcome in the UK and Wales and their attitudes concerning language and integration in Wales. Moreover, a central aspect of this project was the development of a Welsh class for ESOL students. This involved participant observations, as well as carrying out participatory action research which meant formulating and carrying out language teaching according to the participants' needs. In this case, a specific course entitled 'Welsh citizenship class' was formed in order to include aspects of language, identity, culture and history into the teaching contents. Student participants were interviewed about their experiences as a result of the citizenship classes and asked about their perceptions regarding language and integration in Wales.

In the Basque case, the fieldwork was carried out over a period of a semester (approx. 4 months) and involved being a participant-observer in two AISA courses (Basque language courses directed specifically at migrants) organised by the City Council Department of Basque in Vitoria-Gasteiz (22\% Basque speaking; The Basque Institute of Statistics-EUSTAT 2011) and taught by IKA euskaltegi ${ }^{4}$ teachers. This included voice-recording and observations of approximately $52 \mathrm{~h}$ of classroom interaction. In addition, the project included semi-structured individual (26) and group (9) interviews with migrant Basque learners (both students on the AISA course and in euskaltegis). There were overall 63 participants from three different provinces of the BAC: 22 of them were co-participants on the AISA course in Vitoria-Gasteiz, 8 came from outside of the AISA course in Alava, 24 from Guipuscoa and 9 from Biscay). They came from various language backgrounds (a big proportion of them being first language Latin American Spanish speakers-24 participants) and nationalities (Latin Americans, West Africans and Europeans mainly).

\footnotetext{
${ }^{4}$ Euskaltegis are official Basque language schools for adults.

${ }^{5}$ Names of places and relevant documents were left in the text in English.
} 


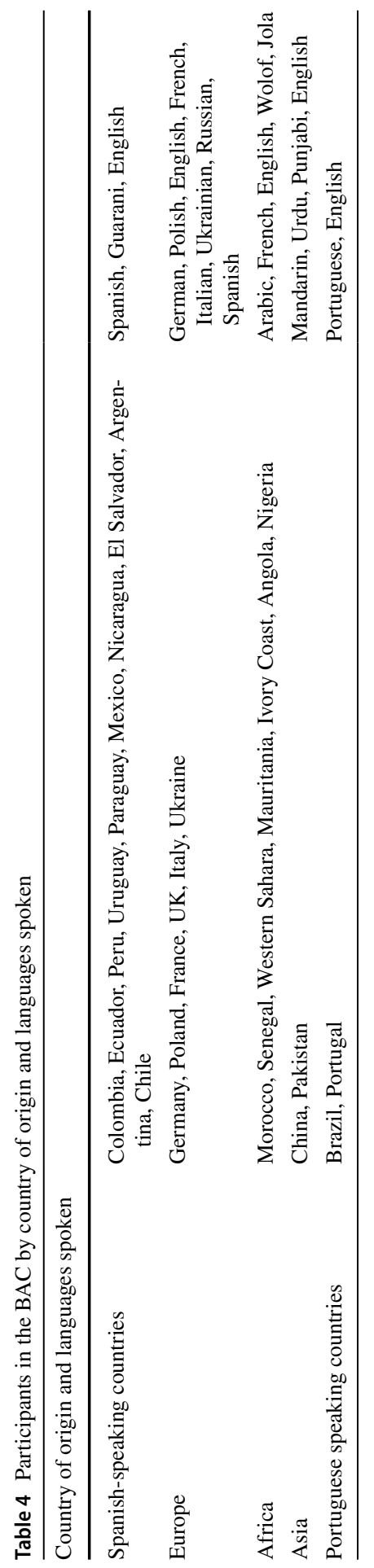


The participants in the Basque study represented a very diversified sample in terms of characteristics relevant to this paper, i.e. first languages spoken, country of origin, age etc. Tables 3 and 4 below show some of these characteristics.

Interviews and group interviews were semi-structured and evolved around the following topics: personal details regarding the length of stay, first language, age and profession, reasons for migrating to the BAC; perceptions of the BAC related to bilingualism, culture, stereotypes, own experiences, social and economic opportunities, integration; perception of 'Basqueness' as a group identity; motivations for study and attitudes towards Basque, opportunities to speak Basque, advantages behind knowing Basque; and perceptions of migrants through the eyes of others, including perceptions of first languages that participants spoke.

Interview data extracts in both cases were also selected through thematic analysis according to their relevance for the discussion on the themes identified in the thematic analysis of documents. We looked at instances of compliance or contestation within the 'ideas that were mentioned in both interview statements and documents' (Bowen 2009: 37) and which would allow for a better representation of the role ascribed to each language in the process of integration. We were especially concerned with highlighting participants' reactions to issues identified in the policy documents, especially in ones which underscored the role of Basque and Welsh for migrants. This allowed for an 'in depth' and 'bottom up' (Nekvapil and Sherman 2015) investigation of the role of languages and language learning in the sub-state territories from the point of view of migrant new speakers. Through highlighting voices of migrant new speakers, we will consider the extent to which they become stakeholders or contest the roles ascribed to them in the policy making process.

\section{Migration and language policy in the Basque and Welsh cases compared}

Migration has been a longstanding concern for both sub-state regions, focused mainly on inward migration from Spain in the case of the BAC, and emigration from other parts of the UK to Wales. Nevertheless, Wales has seen a yearly increase from 101,000 to 180,000 in the number of international immigrants between 2004 and 2011 , with an overall increase of 78\%. Moreover, the latest census results reveal that $33 \%$ of the population of Wales was born outside of Wales. The BAC has shown similar trends, mirroring the immigration process to Spain. The overall percentage of migrant residents in Spain was calculated at 10.1\% in 2015 (which has decreased from its highest level in 2011-12.2\%). In the BAC, migrant population comprises $8.9 \%$ of the entire population of the area (Ikuspegi 2015). This percentage has been growing since 1998, when migrants comprised $1.3 \%$ of the entire BAC's population (ibid.). Although migration figures are not as high in Wales and the BAC compared to the figures in the UK and Spain, attention has recently been directed in sub-state policies at welcoming international migrants. This is reflected in the language and integration policies designed by local governments, which put a certain emphasis on including migrants as possible new speakers of the two sub-state languages. 
In both contexts, there exists what could be referred to as a double-authority (state vs. autonomous government) with regards to migration related issues, including integrating foreign residents (Carrera 2009: 234). Although Wales has no statutory power over the regulation of citizenship and external migration, the Welsh Government exercises powers over education, community cohesion, as well as over the provision of language tuition. An example of this is ESOL (English Speakers of Other Languages) provision which was until recently linked to British Citizenship, but with community cohesion policies and ESOL strategies being propagated by the Welsh Government. In the BAC, the integration of migrants is the responsibility of both authorities, with the state regulating access to citizenship and drafting guidelines for state level integration (as it was done in 2007 by introducing the Strategic Plan of Integration and Citizenship (PECI), and the BAC Government being responsible for the integration process in its own area (Carrera 2009: 278). In this respect, before we continue to make a more detailed comparison between the sub-state language and integration policies and their reception, we will briefly allude to the language and integration policies of both Spain and the UK.

\section{State integration policies: pluralist or civic integration?}

With the increase of migration and diversity, states such as the UK and Spain have distanced from a rights-based approach to diversity management towards what has been called 'the civic turn' (Joppke 2007). This includes requirements such as knowledge of language and history on the part of migrants. Governments have, nevertheless, attempted to fuse these requirements with notions of pluralist ideology, which would include the maintenance of multiculturalism brought about by transnational migration. For example, the Spanish government declares 'the promotion of full integration of migrants in the Spanish society' (Immigration Portal 2016, authors' translation ${ }^{6}$ ), incorporating 'equality, civic responsibility, interculturality and democracy' in order to recognize a full civic, social, economic, cultural and political participation (of migrants) (PECI II 2011: 32). At the same time, the Strategic Plan for Integration and Citizenship 2011-2014 presented by the Spanish Government describes integration as a bidirectional, mutual and universal process, which includes both migrants and the 'host' population. In terms of language learning and its role in the construction of belonging and integration, this Plan specifies 'the learning of languages of the host society' as one of the areas for action, as well as 'the maintaining of (migrants') languages of origin' (PECI II 2011: 159). It also puts emphasis on including the 'existing traditions' as part of the diversity promoted within Spain (PECI II 2011: 96), i.e. the recognition of Spain as a multinational state comprised of a variety of 'local nations', which in terms of the role of language, always refers to migrants' acquisition of 'all existing official languages in Spain' (PECI II 2011: 75; 110).

\footnotetext{
${ }^{6}$ Quotations from Spanish and Basque policy documents are translated into English by the authors of this paper while UK and Welsh policy documents remain in the original English version.
} 
Likewise, the UK Government appears to adopt a pluralist flavour to civic integration, positively embracing cultural diversity of the UK as well as migrants' diverse backgrounds (albeit not explicitly their languages):

The Government welcomes the richness of the cultural diversity which immigrants have brought to the UK-our society is multi-cultural, and is shaped by its diverse peoples. We want British citizenship positively to embrace the diversity of background, culture and faiths that is one of the hallmarks of Britain in the 21st Century (UK Government 2002a: 29).

The Government nevertheless acknowledges that 'knowledge of the English language (or Welsh language or Scottish Gaelic, which are provided for in the British Nationality Act 1981), can undoubtedly support this objective' to construct a civic identity and shared values in the UK (UK Government 2002a: 32).

Despite these claims of shifts from civic integration to pluralistic approaches, state level policies in both cases reveal tensions with regards to the directionality of the integration process, i.e. how these pluralistic and mutual integration processes are to take place and who is subjected to these processes. Emphasis in the Spanish case is given to migrants as 'receivers' of integration, which places the onus on migrants 'adopting positive attitude[s] towards the knowledge of languages' - again, by using a plural noun, including all official languages of the Spanish state. Nevertheless, despite outlining 'measures for the learning of all official languages of the state by migrants', the PECI emphasizes curriculum planning, accreditation and teacher training of Spanish only, by referring to DELE-Diploma de Español como Lengua Extranjera (PECI II 2011: 126). This might be due to the fact that sub-state languages within Spain are only official within their respective autonomous communities (Mar-Molinero 2000a: 99). ${ }^{7}$

Similarly, in the British case, state integration policies' approach to language learning and cohesion treats migrants as objects of integration, with little reference to the contribution of their home languages. Following race riots in England in 2001 and a backlash against the so-called failures of multiculturalism, community cohesion policies have focused on 'shared British values' and a 'shared language' defined by the English language (Higham 2016). Despite acknowledging the other national minority languages, the UK Nationality, Immigration and Asylum Act emphasises 'the ability to speak our common language, to enable them to engage as active citizens in economic, social and political life' (2002b: 30).

What is noteworthy in the two regions is the discrepancy between pluralist declarations and civic, rather assimilative policy reflections in both the UK and Spain, as both states place onus on migrants' responsibility for linguistic integration. In the Spanish case, it is additionally not clear from the policies of whom the host

\footnotetext{
7 The Spanish Constitution of 1978 provided for the existence of two official languages in the autonomous regions (Shabad and Gunther 1982: 4444). However, Article 3 of this legislative document is highly ambiguous, as it proposes that Spanish is the official language of Spain and 'Spaniards have a duty to know Castilian and the right to use it' while other Spanish languages will be official only in the respective autonomous communities (Mar-Molinero 2000a: 88).
} 
communities of such civic integration are made up. Reference is made to the host community as the 'sociedad española', but policies equally refer to various 'host communities' or various languages of integration to a given host community. A lack of clarity concerning the role of the national languages in state integration policies is also visible in the Welsh case, as policies suggest that English is the sole language of integration.

\section{Sub-state integration policies: double integration?}

These discrepancies are visible even more clearly when a comparison between state and sub-state policies is made. As Carrera (2009) points out, local community plans often see integration into their own communities as something different to the integration in Spain as a state, in the sense that these particular sub-state plans stress the need to perceive their own culture as another set of values which migrants need to adhere to. These are perhaps not always represented as fully compatible to the state values (Carrera 2009: 283). This is also visible in Wales in relation to the UK. Following Carrera, we claim that sub-state integration policies 'strengthen the perception of sub-states' own 'imagined communities' societies, language and identity (Carrera 2009: 283; Anderson 1991).

In the same way that state language policies propagate state languages, sub-state policies emphasise the idea of integration through sub-state local languages. However, they do not dismiss the role of the state language, thereby suggesting that integration can in fact be understood as a bilingual process (notwithstanding the difference in numbers of speakers within each sub-state ${ }^{8}$ ). The Basque Policy documents on integration acknowledge the role of both languages in accessing employment ('an enhancement for the learning of languages (Castilian and Basque) as the key element for access to employment' (Basque Government III PVICCI 2011a: 92). However, as far as the integrative role of language is concerned, sub-state languages are given a different emphasis than state languages. In both cases, sub-state integration policies not only underscore the preservation of the sub-state language, but also point to the development and the revitalisation of their respective languages by recruiting new speakers, including migrants.

The Plan of Action for the Promotion of Basque (PAPE) introduced as part of Basque Advisory Board initiative Euskara 21, focuses on the 'production of Basque speakers' (Basque Government 2012: 17). This includes the 'production' of migrant new speakers, as stated in point 8 of this Plan: 'To bring Basque and its contexts closer to immigrants, in order to ease their broad and rewarding integration, as well as to bring Basque closer to the environments of use that are

\footnotetext{
${ }^{8}$ Among the BAC provinces, Guipuscoa has 50\%, Biscay-25\% and Alava 17\% of Basque speakers (Basque Government 2011b: 68). In Wales, the 2011 Census categorises the number and percentages of Welsh speakers via community (Welsh Language Commissioner 2011, see: http://www.comisiynyd dygymraeg.cymru/English/Policy,\%20research\%20and\%20data/Census\%20Data/Pages/2011Censusresul tsbyCommunity.aspx).
} 
demographically dynamic.'(ibid.: 18) In the First Basque Plan of Immigration the local culture and local language learning is particularly emphasised:

On the one hand, it is about ensuring and facilitating the full access by immigrants to the Basque culture, and particularly the learning of the two official languages as part of the integration process. On the other hand, public intervention in this matter pursues the maintenance and development of the immigrants' own cultures within the Basque society and their active participation in the social life (Basque Government I PVICCI 2003: 87).

Similarly, the actions proposed by the 3rd Plan on Immigration (III PVICCI), despite including Castilian as an official language in other contexts, place more emphasis on Basque as a vehicle for integration. One of the projects proposed in this policy plan includes for example: 'Giving a boost to the spaces of collective participation which incorporate Basque as an element of integration' (Basque Government 2011a: 73). In Wales, local and cultural integration is equally emphasised. The Welsh Government policies have made efforts to define Wales' distinctiveness by putting an emphasis on migrants' learning Welsh as well as English:

Wales is an inclusive, multicultural and multi-faith country and we welcome the diversity of migrants, refugees and asylum seekers living in Wales and recognise that whilst they all share a common experience, they are far from homogenous. (...) Wales has a language of its own, that we are rightly proud of. The Welsh Language is spoken throughout Wales, and you will find television and radio programmes, publications and signs in both Welsh and English. We would certainly encourage you to learn Welsh, as well as English (Welsh Government 2010: 4).

Local 'inclusion' which in the Welsh Government's words 'implies a reciprocal and mutually respectful relationship, in which individuals with diverse backgrounds and histories are able to make distinctive contributions to society' is what forms the basis of such integration (Welsh Government 2008:12). Although neither Welsh nor English language skills are explicitly mentioned, it is claimed that 'Good language skills provide firm foundations from which asylum seekers and refugees in Wales can achieve their potential. As well as being the means through which individuals within a community communicate and learn about each other, language carries important cultural and historical signals which can facilitate inclusion' (Welsh Government 2008: 19). Again, in both cases, integration is emphasised as a two-way process bringing mutual benefits to both migrants and host communities. However, there is a strong assertion that the individual sub-state integration policies propose their own culture or cultural elements-such as the sub-state language, as the cultural system to integrate into, in addition to the state system. Both cases suggest learning both languages of the host community and refer to 'Basque' or 'Welsh' society as opposed to 'British' or 'Spanish' society. This would suggest a distinctive sub-state mode of integration which co-exists alongside the nation-state model. 


\section{Contrasting roles of sub-state languages}

Within these sub-state claims to a distinct model of integration, there exist inconsistent claims regarding the value accorded to both sub-state and state language learning, somewhat questioning the merits of bilingualism of the host sub-state in the integration process. We will show that a contrasting value is ascribed to the substate languages in the Welsh an BAC cases.

Despite defining Wales as a bilingual country and encouraging learning both English and Welsh, only a strategy for English (via ESOL_English for Speakers of Other Languages) is put forward. Moreover, the direct link between learning English and community cohesion is re-affirmed in Welsh Government policies, just as in the UK Government policies:

Not being able to communicate in the English language makes it extremely difficult for individuals to fully engage within both our economy and society. We cannot afford for those who migrate to Wales to not be able to participate fully in our communities. We want everyone who lives in Wales to feel a valued part of our society. Hence we must ensure that English language education is available to promote the social inclusion of vulnerable non-English speakers and to ensure that migrant workers can contribute productively to the Welsh economy (Welsh Government 2014: 2).

There are clear links between English-language disadvantage and social exclusion and deprivation. A recent study into poverty and ethnicity in Wales found that English language skills influence 'access to services, people's confidence, their ability to help their children to flourish in school and their social networks' (Welsh Government 2014: 4).

While Welsh is introduced as a 'difficult' language (Welsh Government 2014:7), the policy mentions encouraging an element of Welsh language integration into ESOL classes for the facilitation of English language learning:

Learning ESOL in Wales can provide learners with a greater challenge. Recognising and understanding Welsh place names and signs can be difficult, especially when English is 'alien' as well. Providers need to be conscious of this and help learners to understand the differences. Being a bilingual society provides a richness that can make learning English all the more interesting, and providers are encouraged to integrate the Welsh language into their ESOL classes where possible (Welsh Government 2014: 7).

Unlike in Wales, while the Basque policy is promoting interculturality based on bilingualism and equal access to employment opportunities among either language speakers, Basque is given greater emphasis when it comes to the integrative dimension. The First Basque Plan of Immigration (I PVICCI) stresses the need for creation of public spaces of 'cohabitation' and 'meeting points', which would promote the 'sense of belonging'. Among these, spaces that use Basque are greatly encouraged, as one of the key postulates is 'to enhance spaces of shared participation which incorporate Basque as an element of integration' (Basque Government 2003: 104). 
One more objective mentioned in the 3rd Plan of Integration is the promotion of the AISA course. The course, described as a 'welcome course' designed for migrants 'to learn basic thematic vocabulary to allow migrants to get to know Basque society' (Basque Government 2004), introduces these migrant new speakers into the space of the BAC. This goes in line with the local policy dimension and the role of language in it, as it emphasizes the distinctiveness of the Basque culture and the need to provide migrants with the knowledge of this particular sub-state language. While there exist various initiatives to teach Castilian to migrants (in Vitoria-Gasteiz the city hall indicated at least 7 initiatives in 2015, including NGOs and government organisations; Vitoria City Council 2017), the special design and the promotion of this particular course suggests that it is in fact through Basque that migrants can become better integrated. It represents the distinctiveness of the BAC through referring to the 'Basque society' as separate from the state, Spanish 'imagined community' (Anderson 1991) and perhaps inaccessible or impossible to fully comprehend through Castilian. While such a disproportion or an emphasis on the integrative role of the sub-state language may result from the different statuses of both languages and legal power differences between the autonomous and state governments, it is telling that migrants would be seen as potential new speakers and benefactors of integration through the particular resources of Basque.

In both cases, we see a contradiction in terms of how diversity is represented. In the Basque case, despite mentioning bidirectionality in integration, there is little emphasis on the possibility of bilingual integration (i.e. Basque and Spanish languages) while emphasising migrants' responsibility to integrate into the host society. This integration is understood through an essentialising lens (Jaffe 2007), suggesting that 'Basque society' can only be understood and accessed through Basque language, providing in fact a 'civic' integration, rather than a pluralist one. In the Welsh case, conversely, despite official bilingualism and promoting integrative benefits of Welsh, only English is truly conceptualised as a purposeful language for integration. Only English classes therefore are supported by Government funding, also suggesting a mirroring of UK state and civic integration ideologies.

The comparison in policy documentation has shed light on commonalities in integration policies on the state level and on discrepancies in ideological viewpoints on the sub-state level in both Wales and the BAC. We now turn to migrants' view of these policies by means of ethnographic enquiry in the attempt to compare their viewpoints of migrant new speakers regarding the respective minority language with the ideas put forward by the policy documents on the conceptualisation of language and integration.

\section{The reception of policy by migrants}

\section{Contesting 'local and cultural' integration}

In both cases, our data includes examples of migrants' complying or reporting to comply with the local policy-despite the ambiguous definition of integration, the host community and the type of language resources as a vehicle for integration. In 
the Basque case, migrants suggest they adopt the particular link between the 'distinct Basque culture' and the sub-state language. They understand integration as a process that they need to comply with and this act of complying is realised in their learning of Basque. Language learning becomes an act of respect, as shown in the following episode from an interview in the BAC:

Int: Do you think migrants should learn Basque?

St: I would say so because it is as if you came to Spain and learned Spanish, isn't it? It's a form of showing your respect for the other culture (.) ${ }^{9}$ for the other people (.) that you are different from them but it does not mean you can't share their life (...) their culture.

\section{AISA student from Germany, Vitoria-Gasteiz}

While the bilingualism of the area is acknowledged, the emphasis is on a greater role of Basque as a vehicle for possible social prosperity in addition to 'belongingness'. Similarly, in the Welsh case, the extracts below suggest that Welsh language is also an important language for integration, associated with respect as well as accessing a deeper knowledge of the culture and history of Wales:

I cannot speak Welsh fluently but I always believe that we have to respect our language of the land. (...) It is important for them to speak with local people in their own language. Acceptance will be much easier, that's what I feel.

\section{Welsh Citizenship Class Student from Romania, Cardiff}

I have two reasons for learning Welsh. It's the best way to learn about the Welsh culture and to get to know the local people.

\section{Welsh for Adults Student from Poland, Cardiff}

The Welsh and Basque cases suggest that learning the minoritised language is not merely for acquisition of symbolic capital (Bourdieu 1982) but also as way of profiting from the minoritised linguistic resources as a communicative tool. In this respect, we see that migrants comply with the sub-state integration policies which emphasise the distinctiveness of the minoritised language due to its inherent link with the Basque and Welsh cultural heritage, but also that migrants attribute cultural and social capital to the minoritised language as a tool for integration.

While both contexts stress the importance of local sub-state languages as vehicles for integration, we see that migrants, although adopting integrative motives to a large extent, also contest this dimension of language. This is especially underscored by some participants in Wales who had settled in the capital city of Cardiff, and for whom some jobs require professional knowledge of Welsh, such as local government, councils and education, health and social care services:

Even if it's only for my pride, it is good enough. But it's not the case. It's about business-some jobs require Welsh. At this moment-just some. How I said earlier, maybe in the near future, more and more jobs will require knowing

\footnotetext{
${ }^{9}$ Pauses in speech are marked with (.) and longer pauses or omitted text with (...).
} 
Welsh. This is quite a powerful reason. I can't see any other reason to be honest.

\section{ESOL student from Romania, Cardiff}

The student in the extract above perceives a growing linguistic capital for the minority language and therefore views Welsh as an investment (Peirce 1995). In the BAC, migrants also see the sub-state language as a means to achieve similar goals. First of all, Basque can be regarded by some of the participants as an added-value asset when it comes to employment possibilities (not only in the public sector) —as in the following extract:

I am a communicative person (.) I speak many languages and to open up job possibilities for me too. After all, here in the Basque Country (...) it's better every time if you have (.) it's like an added (...) added value for your CV. Yes.

\section{AISA student from Morocco, Vitoria-Gasteiz}

Secondly, the sub-state language is regarded as a professional asset when it comes to private entrepreneurship and added-value to products produced in Basque (for instance webpages):

(...) being an IT specialist it is not extremely necessary but it's a very good impulse at least here in the Basque Country that you have Basque that you know Basque because at least a little your professional profile can improve because it looks a bit silly but if you are creating a webpage and you need at least a simple phrase you have to call someone who knows Basque so it's convenient that and here all webpages on the internet have to be in Basque.

\section{AISA student from Brazil, Vitoria-Gasteiz}

In both contexts, we observe the minority language as an asset for both cultural and economic integration. Although participants don't consider the minority language by any means equal to the economic value of the state language, participants nevertheless perceive the growing value of the minoritised language. This has been argued elsewhere by Bermingham and Higham (2018) as an expansion of linguistic capital of the minority language. According to Duchêne and Heller's 'pride and profit framework' (2012), the learning of Basque and Welsh is viewed not only as a 'pride' motivation, but also as a 'profit' motivation.

\section{Contesting 'bilingual' integration}

In addition to the increased and varied capital that migrants attribute to Basque and Welsh, migrants challenge the sub-state policies and practices regarding bilingualism as a tool for integration. The following extract further confirms the understanding of Basque identity as separate and connected to language, which can become a tool for integration but also a contestation to this idea:

(...) but with regards to the subject they should have the freedom to choose which ones are their roots to defend their language(.) their language(.) and 
that I agree with (.) that's also why I am studying a little to know more to be able to contact these people who speak Basque.

\section{AISA student from Peru, Vitoria-Gasteiz}

Despite linking Basque with certain essentialising qualities (roots), this Basque learner also recognises that bilingualism is not the reality of everyone in the BAC. Language for her is a tool for becoming fully integrated in the bilingual realm.

In the Welsh case, our findings suggest that immigrants adopt English as the local language of integration due to the direct access to English language provision and the predominance of English in Welsh society. It is noteworthy that in the Welsh situation, migrants show reticence with having to comply with the English language dominant policies, as opposed to respect, showing a desire to invest in the Welsh language. The extract from the Welsh language student below shows clearly the discrepancy in language provision of both English and Welsh:

(...) when I went to Menai College - they were like 'well there are scholarships to learn English for free'. What about Welsh? (...) I was a student so I didn't have much money and I decided to learn English first and when I get money, I would maybe learn Welsh.

\section{Welsh for Adults Student from Spain, Bangor}

If there is a bilingual policy, equal and all, the Government should match the funding. Otherwise, there is no point in saying things that don't happen in Wales at the moment.

\section{Welsh for Adults Student from Spain, Bangor}

It is apparent from the extracts that migrants, though unauthoritative agents in the language policy making process, contest sub-state bilingualism (or lack of it) as a tool for integration. In the Welsh case, it is a contestation concerning a disconnect between policy and practice over provision of the Welsh language tuition for migrants in comparison to English. In the Basque case, apart from contesting the uniquely integrative role of the sub-state language, the findings suggest that migrant learners of Basque contest the implementation of Basque language policy and revitalisation measures. They report the implementation of Basque use as making everyday activities and communication difficult or as being unattainable 'on the ground', despite their own language learning investment. This reflects the fact that migrants' agency and voice might not be taken into account within the policy making process, as evidenced in the following episode from an interview:

I think it's an obligation. They are imposing something that I think is unjust (.) because everyone should be free to choose how they want to speak (.) in Castilian or in Basque (.) so it seems like something imposed and it should not be like this. Because imagine a person (.) or a person that spent (.) or that is of an advanced age (.) and in this moment begins to study Basque (.) if it is difficult for us.

\section{AISA student from Colombia, Vitoria-Gasteiz}


This voice in this particular episode comes across as a postulate for a possibility of choice and an acknowledgement of varying forms of bilingualism, based also on truncated linguistic resources. Through rejecting the role of sub-state language as a solely integrative tool or through representing language policy as an imposition, migrants are, however, positioning themselves as actors who are allowed to have a voice in the policy making process. We can suggest therefore that migrants, albeit without authority in LPP, could be considered agents or even advocates in language policy. This advocacy or voice, we suggest, could become visible if policy studies include ethnographically oriented methods and integrate the construction of migrants' attitudes and their reception of policy.

\section{Discussion and conclusion: migrant voices in sub-state integration policies}

Our research shows that migrant new speakers recognize the status of the host territory as officially bilingual and for this reason desire and expect to gain access to language and employment in both these languages. This suggests that a multidimensional integration needs to include possibilities of economic and social gain rather than a simplistic view of language as a symbolic vehicle for understanding the host community. The ethnographically oriented data shows that migrants (who in many cases have prior experiences of official or non-official multilingualism) contest homogenous assumptions and categorisations of language. By doing this, they desire to own language as a resource (Heller 2003) which has various facets by providing cultural, symbolic and economic capital (Bourdieu 1982).

We therefore propose that migrants who express 'voices' and show agency with regard to language policy should be granted roles of active stakeholders in language policy. How this can be achieved is a more difficult question when policy addresses migrants as receivers of integration instead of 'actors' - thus denying them agency. Applying ethnographically-informed data to the policy making process could, however, bring their voice to the fore. In this respect, our research is compared to other ethnographic work (McCarty 2011) which shows how reviewing language policy from within is beneficial to understanding those who are ultimately affected by policies. In turn, giving 'voice' to migrants may also contribute to addressing inequalities in linguistic provision and opening up new ways for migrants to participate in the host society and paving a path towards meaningful notions of multicultural citizenship. So far though, as Ramanathan (2013) points out, the status quo usually leaves migrants in a position of 'dis-citizenship' in their new host societies.

The BAC and Welsh sub-state policy makers show an increased interest in migrant integration despite having no control over the migration process and national citizenship. This shows the desire to define their own distinct integration models with different emphasis given to state and sub-state languages within their respective territories. This is better understood not only through analysis of policy documents in each sub-state government, but also by including a wide range of ethnographically oriented enquiry. Slicing 'the policy onion' (Hornberger and Johnson 2007) offers a better insight into all policy levels-especially 
related to stakeholders' reception of policy. Our findings confirm the complexity of state and sub-state integration policies, which prove to be abstruse on different levels, constructing the role of sub-state and state languages in ambiguous ways. We have shown that Basque is promoted as the language of integration, suggesting that it is the (main) pathway to belonging and 'Basqueness', while in Wales, more ambiguously, policies promote the cultural assets of the Welsh language, but deliver language learning strategies for migrants solely in English. While language policies promote bilingualism, interculturality and bidirectional cultural exchange between migrants and host communities, a one-dimensional role of language in integration is nevertheless put forward.

The new speaker lens helps to give attention to non-traditional speakers of minoritised languages such as migrant new speakers of Welsh and Basque who contest language categorisations such as integrating into one dominant language and culture. Moreover, new speakerness and 'double' new speakerness moves away from the idea of bounded entities and labeling language competences of speakers towards more fluid concepts that consider languages as processes, practices and repertoires (O'Rourke et al. 2015). Although public debate focuses on migrant inclusion into the nation-state language and culture, examples drawn from Wales and the BAC show that sub-states face similar and particular challenges regarding multicultural integration into minoritised language communities. How the languages and cultures of migrants are recognised and maintained within official bilingualism must also be reviewed. New speaker 'voices' on the ground therefore contribute to highlighting the need for sub-state governments to review their strategies in order to promote inclusivity, cohesion and multinationalism in their nation building projects.

Acknowledgements This work was supported by the European Cooperation in Science and Technology as part of EU COST Action IS1306 entitled 'New Speakers in a Multilingual Europe: Opportunities and Challenges'.

Open Access This article is distributed under the terms of the Creative Commons Attribution 4.0 International License (http://creativecommons.org/licenses/by/4.0/), which permits unrestricted use, distribution, and reproduction in any medium, provided you give appropriate credit to the original author(s) and the source, provide a link to the Creative Commons license, and indicate if changes were made.

\section{References}

Anderson, B. (1991). Imagined communities: Reflections on the origin and spread of nationalism. London: Verso.

Basque Government. (2003). First Basque plan of immigration citizenship and intercultural cohabitation 2003-2005/I Plan Vasco De Inmigración, Ciudadanía Y Convivencia Intercultural 2003-2005 (I PVICCI). Vitoria-Gasteiz.

Basque Government. (2004). HABE. http://www.habe.euskadi.eus/s23-4728/es/contenidos/noticia/aisa/ es_12745/aisa.html. Accessed 31 October 2017.

Basque Government. (2011a). Third Basque plan of immigration citizenship and intercultural cohabitation 2011-2013/III Plan Vasco De Inmigración, Ciudadanía y Convivencia Intercultural (III PVICCI) 2011-2013. Vitoria-Gasteiz.

Basque Government. (2011b). V Sociolinguistic Survey/ V Encuesta Sociolingüística. Vitoria-Gasteiz. 
Basque Government. (2012). Euskara 21. Plan of action for the promotion of Basque/Plan de Acción para la Promoción del Euskera (PAPE). http://blog.euskara21.euskadi.net/?lang_pref=es. Accessed 31 October 2017.

Bermingham, N., \& Higham, G. (2018). Immigrants as new speakers in Galicia and Wales: Issues of integration, belonging and legitimacy. Journal of Multilingual and Multicultural Development, 39(5), 394-406.

Blackledge, A. (2004). Constructions of identity in political discourse in multilingual Britain. In A. Pavlenko \& A. Blackledge (Eds.), Negotiation of identity in multilingual contexts (pp. 68-92). Clevedon: Multilingual Matters.

Blommaert, J. (2014). From mobility to complexity in sociolinguistic theory and method. Tilburg Papers in Culture Studies, 103, 1-24.

Bourdieu, P. (1982). Ce Que Parler Veut Dire. L'économie Des Échanges Linguistiques. Paris: Fayard.

Bowen, G. A. (2009). Document analysis as a qualitative research method. Qualitative Research Journal, 9(2), 27-40.

Burns, A., \& Roberts, C. (2010). Migration and adult language learning: Global flows and local transpositions. Tesol Quarterly, 44(3), 409-419.

Carrera, S. (2009). In search of the perfect citizen?: The intersection between integration, immigration, and nationality in the EU. Leiden: Martinus Nijhoff Publishers.

Duchêne, A., \& Heller, M. (Eds.). (2012). Language in late capitalism: Pride and profit (Vol. 1). London: Routledge.

Extra, G., et al. (Eds.). (2009). Language testing, migration and citizenship: Cross-national perspectives on integration regimes. London: Bloomsbury Publishing.

Heller, M. (2003). Globalization, the new economy and the commodification of language and identity. Journal of Sociolinguistics, 7(4), 473-492.

Higham, G. (2016). Dysgu Cymraeg I Fewnfudwyr: Llunio Llwybr at Ddinasyddiaeth Gynhwysol Gymreig/teaching welsh to immigrants: Paving a pathway towards an inclusive Welsh citizenship. $P h D$, Cardiff. http://orca.cf.ac.uk/96723/1/PhD.pdf.

Hornberger, N. H., \& Johnson, D. C. (2007). Slicing the onion ethnographically: Layers and spaces in multilingual language education policy and practice. TESOL Quarterly, 41(3), 509-532.

Ikuspegi. (2015). Immigration panorama. Foreign population in the BAC 2015/Panorámica de la Inmigración. Población Extranjera en la CAPV 2015. Vitoria-Gasteiz. https://issuu.com/ikuspegi-inmig racion/docs/panoramica57casok. Accessed 31 October 2017.

Jaffe, A. (2007). Discourses of endangerment: Contexts and consequences of essentializing discourses. In M. Heller \& A. Duchêne (Eds.), Discourses of endangerment: Ideology and interest in the defense of languages. London: Continuum.

Joppke, C. (2007). Beyond national models: Civic integration policies for immigrants in Western Europe. West European Politics, 30(1), 1-22.

Keane, W. (2000). Voice. Journal of Linguistic Anthropology, 9(1-2), 271-273.

Kymlicka, W. (2011). Multicultural citizenship within multination states. Etnicities, 11(3), 281-302.

Mar-Molinero, C. (2000a). The politics of language in the spanish-speaking world: From colonization to globalization. London: Taylor \& Francis.

Mar-Molinero, C. (2000b). The Iberian peninsula: Conflicting linguistic nationalisms. In S. Barbour \& C. Carmichael (Eds.), Language and nationalism in Europe. Oxford: OUP.

McCarty, T. L. (Ed.). (2011). Ethnography and language policy. New York: Routledge.

McCarty, T., \& Liu, L. (2011). Ethnography of language policy. In K. A. King, et al. (Eds.) Research methods in language and education. Springer International Publishing. http://www.springer.com/gp/ book/9783319022482. Accessed 23 October 2017.

Nekvapil, J., \& Sherman, T. (2015). An introduction: Language management theory in language policy and planning. International Journal of the Sociology of Language, 232, 1-12.

Norman, W. (2006). Negotiating nationalism, nation-building, federalism, and secession in the multinational state. Oxford: OUP.

O'Rourke, B., et al. (2015). New speakers of minority languages: The challenging opportunity. International Journal of the Sociology of Language, 231, 1-20.

Peirce, B. N. (1995). Social identity, investment, and language learning. TESOL Quarterly, 29(1), 9-31. https://doi.org/10.2307/3587803.

Ramanathan, V. (Ed.). (2013). Language policies and (dis) citizenship: Rights, access, pedagogies. Clevedon: Multilingual Matters. 
Shabad, G., \& Gunther, R. (1982). Language, nationalism and political conflict. Comparative Politics, 19, $134-178$.

Spanish Government. (2007). Strategic plan on integration and citizenship 2007-2010/Plan Estratégico De Ciudadanía E Integración 2007-2010 (PECI I). Madrid.

Spanish Government. (2011). Strategic plan on citizenship and integration 2011-2014 Plan Estratégico De Ciudadanía E Integración 2011-2014 (PECI II). Madrid.

Spanish Government. (2016). Immigration portal/Portal de Inmigración. http://extranjeros.empleo.gob. es/. Accessed 20 June 2018.

UK Government. (2002a). Secure borders, safe haven: Integration with diversity in Modern Britain. London: Home Office. http://dera.ioe.ac.uk/4561/1/cm5387.pdf. Accessed 31 October 2017.

UK Government. (2002b). Nationality, immigration and asylum act 2002. London: Home Office.

UK Government. (2018). Integrated communities strategy green paper. London: UK Government.

Vitoria-Gasteiz City Council. (2017). Frequently asked questions about immigration and interculturality/ Preguntas frecuentes sobre inmigración e interculturalidad. http://www.vitoria-gasteiz.org/we001 /was/we001 Action.do?aplicacion =wb021\&tabla=contenido\&idioma=es\&uid=caeed34_1258c $82 \mathrm{df} 47$ _ffe6. Accessed 31 October 2017.

Welsh Government. (2008). Refugee inclusion strategy. Cardiff: Welsh Government.

Welsh Government. (2009). Getting on together: A community cohesion strategy for Wales. Cardiff: Welsh Government. http://gov.wales/docs/dsjlg/publications/commsafety/091130ccstratenv1.pdf. Accessed 07 November 2017.

Welsh Government. (2010). Understanding Wales. Cardiff: Welsh Government.

Welsh Government. (2012). A living language: A language for living: Welsh language strategy 20122017. Cardiff: Welsh Government. http://gov.wales/docs/dcells/publications/122902wls201217 en.pdf. Accessed 07 November 2017.

Welsh Government. (2014). English for speakers of other languages (ESOL) policy. Cardiff: Welsh Government. http://gov.wales/docs/dcells/publications/140619-esol-policy-en.pdf. Accessed 07 November 2017.

Welsh Government. (2017). Cymraeg 2050: A million Welsh speakers. Cardiff: Welsh Government. http://gov.wales/docs/dcells/publications/170711-welsh-language-strategy-eng.pdf. Accessed 23 October 2017.

Welsh Language Commissioner. (2011). 2011 Census results by Community. http://www.comisiynyd dygymraeg.cymru/English/Policy,\%20research\%20and\%20data/Census\%20Data/Pages/2011Census resultsbyCommunity.aspx. Accessed 12 Feb 2019.

Woolard, K. (2016). Singular and plural: Ideologies of linguistic authority in twenty-first century catalonia. New York: Oxford University Press.

Publisher's Note Springer Nature remains neutral with regard to jurisdictional claims in published maps and institutional affiliations.

Anna Augustyniak is an associate researcher at CIES-IUL - Centre for Research and Studies in Sociology (ESPP) of the University Institute of Lisbon, Portugal. She is included in the project: Trovoada de Ideias - Linguistic and social inclusion of Students from the PALOP in the Portuguese Higher Education. In her research she mainly focuses on issues of language, identity and migration in minority language (particularly Basque) and disadvantaged populations contexts.

Gwennan Higham is a lecturer at the Welsh Department, Swansea University. Her research is focused on issues around migration, education, citizenship and the Welsh language. She is currently working on the Erasmus+ COMBI project to develop language resources for migrants in bilingual workplaces. 